\title{
On the natural history of the Caatinga Horned Frog, Ceratophrys joazeirensis (Anura: Ceratophryidae), a poorly known species of northeastern Brazil
}

Jaqueiuto da Silva Jorge1, Raul Fernandes Dantas Sales', Marcelo Nogueira de Carvalho Kokubum², and Eliza Maria Xavier Freire ${ }^{1}$

\footnotetext{
${ }^{1}$ Laboratório de Herpetologia, Departamento de Botânica e Zoologia, Centro de Biociências, Universidade Federal do Rio Grande do Norte, Campus Universitário, Lagoa Nova, CEP 59078-970, Natal, Rio Grande do Norte, Brazil. E-mails: queilto@ yahoo.com.br, raulsales17@gmail.com, elizajuju1000@gmail.com.

${ }^{2}$ Laboratório de Herpetologia, Unidade Acadêmica de Ciências Biológicas e Programa de Pós-graduação em Ciências Florestais, CSTR, Universidade Federal de Campina Grande, UFCG, CEP 58704-330, Patos, Paraíba, Brazil. E-mail: mnckokubum@gmail.com.
}

\begin{abstract}
On the natural history of the Caatinga Horned Frog, Ceratophrys joazeirensis (Anura: Ceratrophryidae), a poorly known species of northeastern Brazil. Data on reproduction, sexual dimorphism, and the diet of Ceratophrys joazeirensis, the only species of the genus that occurs in the Brazilian semiarid Caatinga Biome, are presented. Anurans were observed and collected in Santa Maria Municipality, state of Rio Grande do Norte in northeastern Brazil. Fieldwork was conducted at night either after or during rains throughout the rainy season in 2010-2013. Searches were conducted near places where males were calling, usually around the perimeters of bodies of water. Reproduction is explosive in the population, with breeding activity occurring as the rain intensified during the rainy seasons of 2011-2013. However, in 2010, neither calling males nor active females were found, even after rainy days. Although males call in temporary and permanent ponds, most males call in the marginal vegetation of temporary ponds. Females $C$. joazeirensis are significantly larger than males. The average clutch size is $2555.0 \pm 1551.1$ eggs; clutch size is not significantly correlated with female body size. In decreasing order of volume, the most important prey categories in the diet of $C$. joazeirensis are anurans, followed by coleopterans and plant material. The apparent importance of anurans in the diet probably is related to the number of anuran species that co-occur with $C$. joazeirensis and the voracious feeding behavior of ceratophryids.
\end{abstract}

Keywords: Anura, Caatinga, diet, reproduction, sexual dimorphism.

Received 8 June 2015.

Accepted 24 September 2015.

Distributed December 2015. 


\begin{abstract}
Resumo
Sobre a história natural do Sapo-de-chifre da Caatinga, Ceratophrys joazeirensis (Anura: Ceratophryidae), uma espécie pouco conhecida do nordeste do Brasil. Apresentamos aqui dados sobre a reprodução, dimorfismo sexual e dieta de Ceratophrys joazeirensis, a única espécie do gênero que ocorre no Bioma brasileiro semiárido Caatinga. Os anuros foram observados e coletados no Município de Santa Maria, estado do Rio Grande do Norte, nordeste do Brasil. O trabalho de campo foi realizado à noite, durante ou após as chuvas ao longo da estação chuvosa no período 2010-2013. Foram realizadas buscas perto de locais onde os machos estavam vocalizando, geralmente em torno de corpos d'água. A reprodução é explosiva, com atividade reprodutiva ocorrendo quando as chuvas se intensificaram durante as estações chuvosas de 2011-2013. No entanto, em 2010, nem machos vocalizando nem fêmeas ativas foram encontrados, mesmo depois de dias chuvosos. Embora os machos vocalizem em poças temporárias e permanentes, a maioria dos indivíduos vocalizou na vegetação marginal de poças temporárias. As fêmeas de C. joazeirensis são significativamente maiores que os machos. O tamanho médio da desova é de $2555.0 \pm 1551.1$ ovos; o tamanho da ninhada não está significativamente correlacionado com o tamanho do corpo das fêmeas. Em ordem decrescente de volume, as categorias de presas mais importantes na dieta de $C$. joazeirensis foram anuros, seguidos por coleópteros e material vegetal. A aparente importância dos anuros na dieta provavelmente está relacionada com o número de espécies de anuros que co-ocorrem com $C$. joazeirensis e do comportamento alimentar voraz dos Ceratophryidae.
\end{abstract}

Palavras-chave: Anuros, Caatinga, dieta, dimorfismo sexual, reprodução.

\section{Introduction}

Ceratophryid frogs are characterized by large heads and jaws, wide gapes, hyperossified skulls, and fang-like teeth (Wild 1997). They are voracious predators that use a sit-and-wait feeding strategy to ambush prey, which includes ants and small vertebrates, such as frogs (Duellman and Lizana 1994, Wells 2007). Ceratophryids are explosive breeders; their macrophagic carnivorous larvae develop rapidly in ephemeral ponds where they usually breed and undergo extremely rapid development (Wild 1997). Within Ceratophryidae, Ceratophrys Wied-Neuwied, 1824, is the most species-rich genus, with eight species distributed throughout tropical South America (Vieira et al. 2006a, Santana et al. 2014, Frost 2015).

Ceratophrys joazeirensis was described by Mercadal (1986), from Juazeiro Municipality in the state of Bahia in northeastern Brazil (Figure 1 ); it is the only species of the genus that occurs in the Caatinga Biome. Currently, the species is known to occur in the Brazilian states of Bahia
(Mercadal 1986, Zaidan and Leite 2012), Paraíba (Vieira et al. 2006a), Rio Grande do Norte (Vieira et al. 2006a, Jorge et al. 2012), Pernambuco (Santos et al. 2009), Piauí (Roberto et al. 2013), Minas Gerais (Maciel et al. 2013), and Sergipe (Santana et al. 2014; Figure 1). Ceratophrys joazeirensis is poorly known because of its ecology, cryptic coloration, relatively rarity in nature, and activity that is limited to the rainy season. Similar features characterize congeners, such as Ceratophrys stolzmanni (Ortiz et al. 2013) and Ceratophrys cornuta (Duellman and Lizana 1994). There is little information about the natural history of Ceratophrys joazeirensis (Skuk and Junca 2004, Schalk et al. 2014), save for two studies reporting acoustical parameters of the advertisement call (Zaidan and Leite 2012, Maciel et al. 2013), and one study describing the warning and distress calls (Toledo and Haddad 2009).

Knowledge of natural history is critical to conservation strategies for Ceratophyrs joazeirensis; currently, it is categorized as "Data deficient" in the IUCN Red List (Skuk and Juncá 
2004). Herein, we provide data on reproduction, sexual dimorphism, and diet of a population of C. joazeirensis in a semiarid area in the state of Rio Grande do Norte in northeastern Brazil. We sought to determine whether (1) breeding activity is prolonged or explosive, (2) there is sexual dimorphism in the population. and (3) clutch size is correlated with female body size, as well as (4) identify the composition of the diet of the population.

\section{Materials and Methods}

\section{Study Area}

The study was conducted at Fazenda Tanques (5.854 ${ }^{\circ} \mathrm{S}, 35.701^{\circ} \mathrm{W}$; datum WGS 84, elev. 137 $\mathrm{m})$, municipality of Santa Maria, state of Rio Grande do Norte, Brazil (Figure 1), an area included in the "Depressão Sertaneja Setentrional" Ecoregion of the Caatinga Biome (Velloso et al. 2002). This ecoregion is characterized by irregular rainfall and a dry season from July to December. The climate is semiarid, hot, and dry, with an average annual precipitation of 500-800 mm/year (Velloso et al. 2002). The municipality of Santa Maria is located in the "Agreste" region, a transition zone between the Caatinga and the Atlantic Forest, with characteristics of both environments (Rizzini 1997). The rainy season in the "Agreste" usually extends from January-June (Velloso et al. 2002). In Santa Maria, minimum monthly temperatures range from $22-24^{\circ} \mathrm{C}$ and maximum monthly temperatures from $28-32^{\circ} \mathrm{C}$, with an average annual rainfall of $781 \mathrm{~mm}$ (Figure 2).

\section{Methodological Procedures}

Fieldwork was conducted during the rainy months from December-July. Anurans were observed and collected by JSJ for three consecutive days in each month either after or during rainy nights from 2010-2013. April 2012 was an exception because two field excursions on each of three consecutive days. Observations

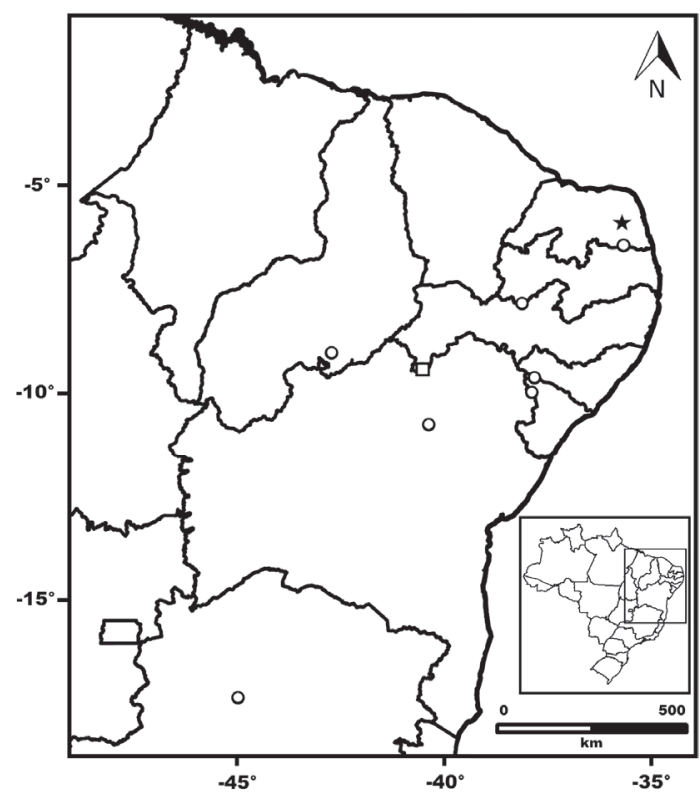

Figure 1. Geographic distribution of Ceratophrys joazeirensis in Brazil. The black star indicates the study area (Santa Maria Municipality in Rio Grande do Norte) and the white square is the type locality (Juazeiro Municipality in Bahia; Mercadal 1986); the white circles are literature records. For names and geographic coordinates of all localities see Santana et al. (2014).

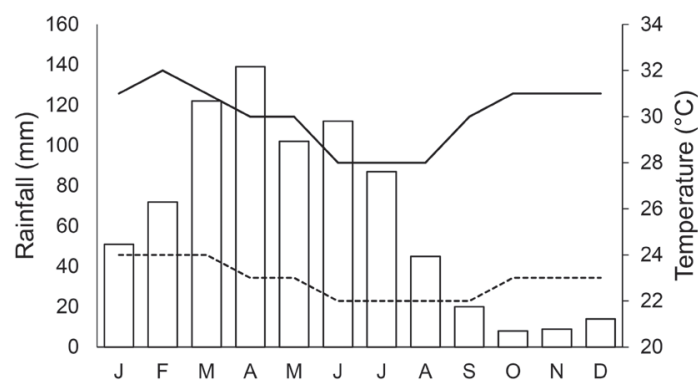

Figure 2. Rainfall (bars) and average maximum (solid line) and minimum (dotted line) monthly temperatures in Santa Maria Municipality, Rio Grande do Norte state, northeastern Brazil. Values are averages of a series of 30 years. Source: Climatempo website (www. climatempo.com.br). 
usually were made between 17:00 h and 00:00 h, and sometimes extended to 03:00 h. The total number of sampling hours from 2010-2013 was $208 \mathrm{~h}$. Searches were intensified in places where male $C$. joazeirensis were calling, usually at the edges of bodies of water. When possible, frogs were collected by hand. Bodies of water were classified according to the following features: (1) temporary versus permanent bodies of water; (2) appearance of water (clear versus o); (3) origin the water body (formed naturally or artificially, as a result of human activity); and (4) presence or absence of surrounding vegetation.

The frogs were euthanized by immersion in ethanol $10 \%$ (according to the Resolution of the Federal Council of Biology-CFBio No. 301, 8 December 2012). The following measurements made with digital calipers (to nearest $0.1 \mathrm{~mm}$ ) were recorded for each individual prior to fixation: snout-vent length (SVL), head width (HW), jaw length (JL), forelimb length (FLL), and hind-limb length (HLL). The frogs were then dissected to confirm the sex and to remove the stomachs. All specimens were fixed in 10\% formalin, preserved in $70 \%$ ethanol, and deposited at the Herpetological Collection of Universidade Federal do Rio Grande do Norte (voucher numbers: UFRN 3633, 3760, 38583860, 4467-4474).

We determined sex by direct examination of gonads. In females, we measured the diameter of the eggs. We considered the largest and most pigmented eggs as mature (Crump 1974). We estimated mean number of eggs per clutch based on the number of mature ovarian eggs found in the ovaries of the gravid females.

We examined the stomach contents under a stereomicroscope to identify the food items. We measured the length and width of each prey item with a millimeter-ruled graph paper, and the volume was estimated by the formula for a prolate spheroid: $\mathrm{V}=4 / 3 \pi($ length $/ 2)(\text { width } / 2)^{2}$ (Dunham 1983). We determined the frequency of occurrence of each prey category $(\mathrm{F} \%)$ as the number of stomachs containing the prey category $i$, divided by the total number of stomachs. We also calculated the numeric $(\mathrm{N} \%)$ and volumetric (V\%) percentages of each prey category for the pooled stomachs. We calculated the importance index (I) for each prey category by the following formula: $\mathrm{I}=(\mathrm{F} \%+\mathrm{N} \%+\mathrm{V} \%) / 3$ (Mesquita and Colli 2003).

We tested for sexual differences in SVL through and independent t-test (Zar 1999). To evaluate the existence of sexual differences in the other morphometric measures (HW, JL, FLL, HLL), we performed covariance analyses (ANCOVA) using SVL as a covariate (Zar 1999). To test the relationship between the female body size and clutch size, we performed a simple linear regression analysis (Zar 1999). Before performing all parametric tests, all variables were tested for normality and homoscedasticity of variances. Throughout the text, descriptive statistics are represented as mean $\pm \mathrm{SD}$.

\section{Results}

\section{Breeding Activity}

Breeding activity in the population of Ceratophrys joazeirensis that we studied is explosive and occurred during the rainy season in the years 2011, 2012, and 2013. In 2010, we did not encounter calling males (Table 1) or active females, even after rains. The only active individual we found in 2010 was a male that was collected next to a temporary pond on a dry day in April 2010. The male was silent and probably was foraging in the soil. The dorsal coloration of this male (dark brown with yellowish spots) differed from the other individuals (both males and females) encountered during rainy nights in the years 2011 to 2013; the latter varied from light green to dark green, with yellow spots along the body (Figure 3).

From 2011-2013, frogs were observed only after heavy rains, and were active throughout the night. Calling commenced around 18:30 h (postsunset) and peaked between 20:00 and 23:00 h; we also recorded some individuals calling until 
03:00 $\mathrm{h}$ of the next morning. In 2011, we recorded males calling and oviposition in temporary ponds in April and June (Table 1). In 2012, males called from February-April (Table 1), and on some nights in April 2012, we counted about 10 males calling at the same time in temporary ponds. In 2013, we observed males calling from February-April, and in June (Table 1); gravid females were collected during the same period, February-April, and in June.

Although male Ceratophrys joazeirensis called at both permanent and temporary ponds, most individuals were found in temporary ponds. Ephemeral ponds last a month or two after the rains end, and are characterized by clear water (usually transparent) resulting from recent rains and herbaceous vegetation at the edge of the water. The only permanent pond in the study area (a reservoir built for agriculture) had more turbid water and lacked marginal vegetation. We usually encountered three males calling at the same time in a single temporary pond. Males usually call in the vegetation surrounding the pond edges; females, in contrast remain in the water and move toward the males. Males were separated from one another by at least $5 \mathrm{~m}$. Only two males were observed calling in the permanent pond during the entire study, and no females were found. Several other anuran species call in the temporary ponds with $C$. joazeirensis-viz., Physalaemus cicada, Physalaemus cuvieri, Physalaemus albifrons, Pleurodema diplolister, Pseudopaludicola pocoto, Leptodactylus troglodytes, Leptodactylus fuscus, Scinax x-signatus, and Elachistocleis cesarii. We did not collect any tadpoles or observe any juveniles of $C$. joazeirensis during the surveys.

\section{Morphometrics}

The average SVL of females is significantly greater than that of males $(\mathrm{t}=-6.238, \mathrm{df}=11, p$ $<0.001$; Table 2). Males and females do not differ, however, with respect to the other morphometric variables (Table 2).

\section{Fecundity}

Four of the six females collected had oocytes. The average clutch size is $2555.0 \pm 1551.1 \mathrm{eggs}$ (range: $1.289-4.063 ; N=4$ ), and the average egg diameter is $1.69 \pm 0.22 \mathrm{~mm}$ (range: $1.22-2.13, N$ =30). The eggs are black in the center, and light yellow peripherally. Female body size and clutch size are not significantly correlated $\left(\mathrm{R}^{2}=0.292\right.$, $\mathrm{F}=0.823, p=0.460)$.

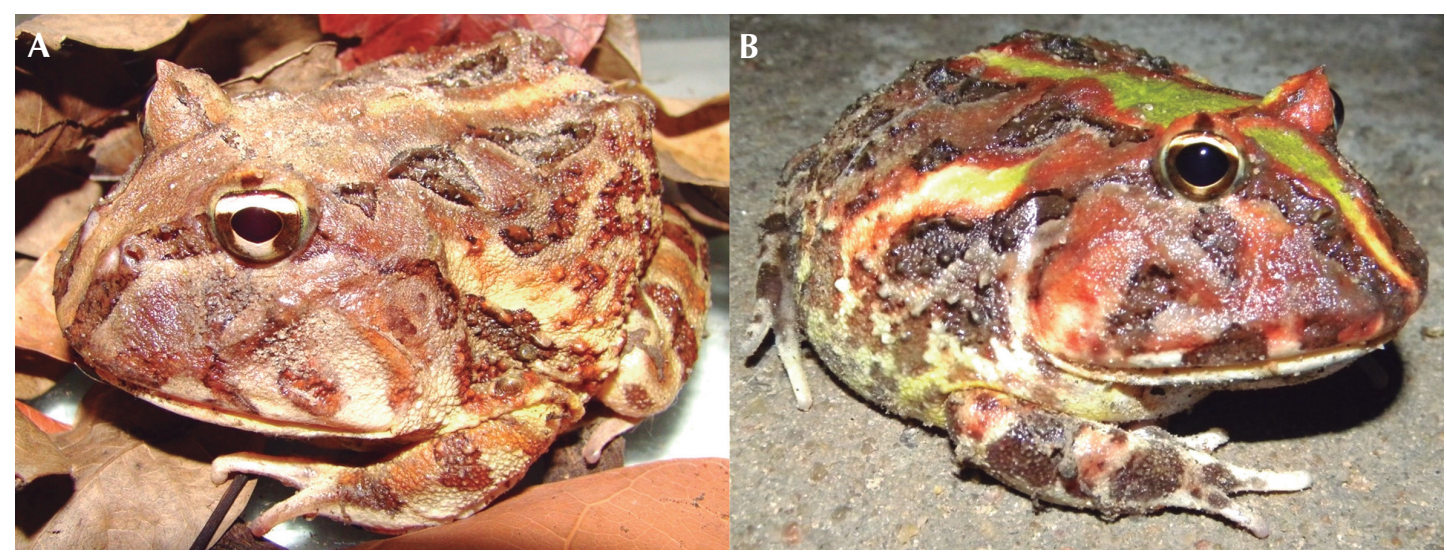

Figure 3. Adult Ceratophrys joazeirensis collected in Santa Maria Municipality, showing the difference in coloration during the non-reproductive (A; a male) and reproductive period (B; a female). Males and females have the same color pattern during the breeding season. Photos: Jaqueiuto Jorge. 
Table 1. Breeding activity of Ceratophrys joazeirensis by month in Fazenda Tanques, Santa Maria Municipality, Rio Grande do Norte state, northeastern Brazil, during the years 2010-2013.

\begin{tabular}{cccccccc}
\hline & \multicolumn{7}{c}{ Months } \\
\cline { 2 - 7 } Years & Jan & Feb & Mar & Apr & May & Jun & Jul \\
\hline 2010 & - & - & - & - & - & - & - \\
2011 & - & - & - & X & - & X & - \\
2012 & - & X & X & X & - & - & - \\
2013 & - & X & X & X & - & X & - \\
\hline
\end{tabular}

Diet

We identified six prey categories in the diet of C. joazeirensis (Table 3). The importance index revealed that the most abundant prey category was anurans, followed by coleopterans and plant material (Table 3). Anurans represented $68.8 \%$ of total number of prey items ingested, and represented $75.8 \%$ of the total volume (Table 3 ). Anurans were found in the stomachs of three C. joazeirensis; each of two stomachs had five anurans, and one stomach had one anuran, as follow: Pleurodema diplolister $(N=3)$, Physalaemus cicada $(N=3)$, Physalaemus cuvieri $(N$ = 2), Physalaemus albifrons $(N=1)$, Rhinella granulosa $(N=1)$. In one case, digestion of the prey frog precluded its identification. The average number of prey items per stomach was $3.0 \pm 1.8$ (range: $1-5$ ), and average total stomach volume was $11904.1 \pm 9641.8 \mathrm{~mm}^{3}$ (range: $\left.234.2-25729.1 \mathrm{~mm}^{3}\right)$. Of the 13 stomachs examined, six (46.15\%) were empty (three males and three females).

\section{Discussion}

Our field observations suggest that like its congeners, Ceratophrys joazeirensis is an explosive breeder, with its tadpoles developing rapidly in ephemeral ponds (Wild 1997, Wells

Table 2. Summary of morphometric characters (in $\mathrm{mm}$ ) of females and males of Ceratophrys joazeirensis. See methods for abbreviations and statistical descriptions. Values in parentheses represent ranges. P-values marked with an asterisk $(*)$ indicate significant differences between the groups.

\begin{tabular}{lccc}
\hline Variables & Females $(\mathbf{N}=\mathbf{6})$ & Males $(\mathbf{N}=7)$ & Statistics \\
\hline SVL & $96.6 \pm 7.0(84.6-103.9)$ & $78.1 \pm 3.4(74.3-83.0)$ & $\mathrm{t}=-6.238, \mathrm{df}=11, p<0.001^{*}$ \\
$\mathrm{HL}$ & $51.7 \pm 2.8(48.7-55.4)$ & $43.2 \pm 2.2(40.2-46.4)$ & $\mathrm{F}_{1,10}=2.938, p=0.117$ \\
$\mathrm{JL}$ & $43.9 \pm 4.1(36.4-47.3)$ & $35.8 \pm 5.1(28.5-42.2)$ & $\mathrm{F}_{1,10}=1.734, p=0.217$ \\
$\mathrm{FLL}$ & $47.4 \pm 9.7(38.4-62.9)$ & $38.1 \pm 7.7(25.6-51.6)$ & $\mathrm{F}_{1,10}=1.374, p=0.268$ \\
$\mathrm{HLL}$ & $85.8 \pm 13.5(72.0-110.9)$ & $76.3 \pm 7.4(67.6-87.5)$ & $\mathrm{F}_{1,10}=2.653, p=0.134$ \\
\hline
\end{tabular}


Table 3. Dietary composition of Ceratophrys joazeirensis $(N=13)$ in Fazenda Tanques, Santa Maria Municipality, Rio Grande do Norte state, northeastern Brazil. $\mathrm{F}=$ frequency of occurrence, $N=$ number, $\mathrm{V}=$ volume $\left(\mathrm{mm}^{3}\right), \mathrm{I}=$ importance index, UVR = unidentified vertebrate remains, UAR = unidentified arthropod remains. Empty stomachs $(N=6)$ were not considered to calculate the frequency of occurrence.

\begin{tabular}{|c|c|c|c|c|}
\hline Prey category & $F(\%)$ & $N(\%)$ & V (\%) & I \\
\hline Anura & $3(42.9)$ & $11(68.8)$ & 58918.35 (75.8) & 62.5 \\
\hline Coleoptera (adult) & $2(28.6)$ & $2(12.5)$ & $6746.06(8.7)$ & 16.6 \\
\hline Coleoptera (larvae) & $1(14.3)$ & $1(7.7)$ & $89.58(0.1)$ & 7.4 \\
\hline Lepidoptera (larvae) & $1(14.3)$ & $1(7.7)$ & $1496.27(1.9)$ & 8.0 \\
\hline Hymenoptera & $1(14.3)$ & $1(7.7)$ & $579.03(0.8)$ & 7.6 \\
\hline Plant material & $2(28.6)$ & - & $4298.46(5.5)$ & 17.1 \\
\hline UVR & $1(14.3)$ & - & $4282.01(5.5)$ & - \\
\hline UAR & $2(28.6)$ & - & 1276.65 (1.6) & - \\
\hline TOTAL & 7 (100) & $16(100)$ & 77686.41 (100) & \\
\hline
\end{tabular}

2007). Rainfall triggers reproductive activity in C. joazeirensis, as it does in other ceratophryids, such as C. ornata in Argentina (Basso 1990), Chacophrys pierottii in Paraguay (Cei 1955), C. cornuta in the Peruvian Amazon (Duellman and Lizana 1994), C. stolzmanni in Ecuador (Ortiz et al. 2013), and C. cranwelli in Bolivia (Schalk and Saenz 2015). Many anurans breed in ponds; the quality of pond water is extremely important, because species richness and productivity in the pond are directly correlated with hydroperiod (Wilbur 1987). We noted that ephemeral ponds dry up within a few weeks. The timing of metamorphosis of anuran larvae must respond to this desiccation Egg clutchs are deposited in a mass in $C$. joazeirensis; they resemble those of C. stolzmanni (Ortiz et al. 2013). In contrast, $C$. ornata deposits single, isolated eggs (Basso 1990).

We found most individuals of $C$. joazeirensis in the surrounding herbaceous vegetation of ephemeral ponds; only two males were found calling near a permanent pond at our study site in the Brazilian Caatinga. In the Bolivian Gran Chaco, all $C$. cranwelli were observed near ephemeral ponds (Schalk and Fitzgerald 2015). Most $C$. cornuta in the Peruvian Amazon are found in the leaf litter of the forest, with a few individuals in the vicinity of bodies of water (Duellman and Lizana 1994); this pattern of habitat usage differs from that observed for $C$. joazeirensis herein, and $C$. cranwelli in the Bolivian Gran Chaco (Schalk and Fitzgerald 2015).

Ceratophrys joazeirensis has Reproductive Mode 1 of Duellman and Trueb (1986), with eggs and feeding tadpoles in lentic water, as do other species of Ceratophrys (Ortiz et al. 2013). The reproductive mode and strategy of $C$. joazeirensis closely resembles that of $C$. cranwelli; males call at the beginning of the rainy season at ephemeral ponds for a short breeding period (Schalk and Saenz 2015) and females deposit multiple egg masses around the pond, which hatch into carnivorous tadpoles (Lavilla and Scrocchi 1990, Perotti 1997). The 
morphology and biology of the larvae of $C$. joazeirensis, however, are unknown.

Adult Ceratophrys joazeirensis probably burrow in the substrate during the dry season at the study site. Many anurans in arid regions remain inactive in deep burrows for many months each year and emerge only after heavy rains for brief periods of breeding and foraging (Wells 2007). In contrast to caecilians and salamanders, which are largely restricted to burrowing in moist soils, many frogs spend considerable periods of time in relatively dry soils (Wells 2007). Burrowing may be the single most common adaptation for avoiding desiccation among anurans from deserts, savannas, and other dry environments (Main et al. 1959, Wells 2007). Additionally, ceratophryids develop a cocoon of dead skin to reduce water loss during aestivation (Faivovich et al. 2014). This cocoon has been considered a specialization associated with semiarid environments (McClanahan et al. 1976).

The sexual dimorphism in size in $C$. joazeirensis, with females being larger than males, also occurs in $C$. cranwelli (Mercadal 1986). These species share many similarities in the morphology of the forelimbs and hind limbs according to Mercadal (1986). However, they differ in the number of chromosomes in somatic cells; $C$. cranwelli is a diploid $(2 \mathrm{n})$, and $C$. joazeirensis an octoploid (8n) (Vieira et al. 2006b). The larger size of females of $C$. joazeirensis may enable females to carry larger clutches, as proposed for others ectotherms (Pianka and Parker 1975, Shine 1977). However, we did not find a positive correlation between female size and clutch size; this may be a small sampling error.

Frogs of the genus Ceratophrys have wide mouths that accommodate ingestion of large prey; they are voracious predators on other anurans (Duellman and Trueb 1986, Scott Jr. and Aquino 2005). The diet of $C$. joazeirensis (anurans and coleopterans) resembles that of $C$. cranwelli, in which frogs also are the primary prey (Schalk and Montaña 2011, Schalk et al.
2014). According to the classification of Toledo et al. (2007), C. joazeirensis can be considered a "convenience" predator on other anurans. Although not an anuran specialist, $C$. joazeirensis feeds opportunistically on frogs sharing its habitat, thereby facilitating predator-prey encounters. The anuran species registered as prey (Pleurodema diplolister, Physalaemus spp., Rhinella granulosa) are the most abundant species at the sites where $C$. joazeirensis occurred (pers. obs.). Ceratophrys joazeirensis is a sit-and-wait predator, as are other species of Ceratophrys (Duellman and Lizana 1994, Schalk et al. 2014).

The results of the study contribute to the knowledge of $C$. joazeirensis, but several aspects of its natural history remain unknown, such as the viability of oocytes, fertilization rates, development time, and the biology of tadpoles. Future studies of these topics will inform our understanding of the biology of this species.

\section{Acknowledgments}

This study was supported by research grants from the Conselho Nacional de Desenvolvimento Científico e Tecnológico (CNPq) to JSJ (Process 130363/2014-6) and EMXF (Process 309424/ 2011-9), and from the Coordernação de Aperfeiçoamento de Pessoal de Nível Superior (CAPES) to RFDS. The permit to collect the specimens was issued by Sisbio/IBAMA (permanent permit number 12734-1). We also thank Bruno Rego and Ingrid Caroline for their help in identifying the material.

\section{References}

Basso, N. G. 1990. Estrategias adaptativas en una comunidad subtropical de anuros. Cuadernos de Herpetología 1: $1-72$.

Cei, J. M. 1955. Chacoan batrachians in central Argentina. Copeia 1955: 291-293.

Crump, M. L. 1974. Reproductive strategies in a tropical anuran community. University of Kansas, Museum of Natural History, Miscellaneous Publication 61: 1-68. 
Duellman, W. E. and L. Trueb (eds.). 1986. Biology of Amphibians. New York. McGraw-Hill Publishing Company. 670 pp.

Duellman, W. E. and M. Lizana. 1994. Biology of a sit andwait predator, the leptodactylid frog Ceratophrys cornuta. Herpetologica 50: 51-64.

Dunham, A. E. 1983. Realized niche overlap, resource abundance, and intensity of interspecific competition. Pp. 261-280 in R. B. Huey, E. R. Pianka, and T. W. Schoener (eds.), Lizard Ecology: Studies of a Model Organism. Cambridge. Harvard University Press.

Faivovich, J., L. Nicoli, B. L. Blotto, M.O. Pereyra, D. Baldo, J. S. Barrionuevo, M. Fabrezi, E. R. Wild, and C. F. B. Haddad. 2014. Big, bad, and beautiful: phylogenetic relationships of the Horned Frogs (Anura: Ceratophryidae). South American Journal of Herpetology 9: 207-227.

Frost, D. R. (ed.). 2015. Amphibian Species of the World: an Online Reference. Version 6.0 (28 April 2015). Electronic Database accessible at http://research.amnh. org/vz/herpetology/amphibia/index.html. American Museum of Natural History, New York, USA. Captured on 17 March 2015.

Jorge, J. S., M. N. C. Kokubum, R. F. D. Sales, and E. M. X. Freire. 2012. Geographic distribution: Ceratophrys joazeirensis. Herpetological Review 43: 297-298.

Lavilla, E. O. and G. J. Scrocchi. 1990. Ceratophrys cranwelli (Escuerzo). Oviposition. Herpetological Review 21: 18-19.

Maciel, N. M., M. N. C. Kokubum, P. H. P. Braga, A. T. Queiróz-Júnior, and R. H. Matsushita. 2013. Distribution extension, new state record and geographic distribution map of Ceratophrys joazeirensis Mercadal, 1986 (Anura: Ceratophryidae). Herpetology Notes 6: $447-$ 450.

Main, A. R., M. J. Littlejohn, and A. K. Lee. 1959. Ecology of Australian frogs. Pp. 396-411 in A. Keast, R. L. Crocker, and C. S. Christian (eds.), Biogeography and Ecology in Australia. Monographiae Biologicae Vol. 8. Dr. W. Junk : The Hague.

McClanahan, L. L., V. H. Shoemaker, and R. Ruibal. 1976. Structure and function of the cocoon of a Ceratophryd frog. Copeia 1976: 179-185.

Mercadal, I. T. 1986. Ceratophrys joazeirensis sp. n. (Ceratophryidae, Anura) del nordeste de Brazil. Amphibia-Reptilia 7: 313-334.

Mesquita, D. O. and G. R. Colli. 2003. The ecology of Cnemidophorus ocellifer (Squamata, Teiidae) in a neotropical savanna. Journal of Herpetology 37: 498-509.
Ortiz, D. A., D. Almeida-Reinoso, and L. A. Coloma. 2013. Notes on husbandry, reproduction and development in the Pacific horned frog Ceratophrys stolzmanni (Anura: Ceratophryidae) with comments on its amplexus. International Zoo Yearbook 47: 151-162.

Perotti, M. G. 1997. Modos reproductivos y variables reproductivas cuantitativas de un ensamble de anuros del Chaco semiárido, Salta, Argentina. Revista Chilena de Historia Natural 70: 277-288.

Pianka, E. R. and W. S. Parker. 1975. Age-specific reproductive tactics. Amercian Naturalist 109: 453-464.

Rizzini, C. T. 1997. Tratado de Fitogeografia do Brasil: Aspectos Ecológicos, Sociológicos e Florísticos. 2 edição. Rio de Janeiro. Âmbito Cultural Edições. 747 pp.

Roberto, I. J., S. C. Ribeiro, and D. Loebmann. 2013. Amphibians of the state of Piauí, Northeastern Brazil: a preliminary assessment. Biota Neotropica 13: 322-330.

Santana, D. O., R. G. Faria, F. L. S. Caldas, and C. B. Carvalho. 2014. Ceratophrys joazeirensis Mercadal, 1986 (Anura: Ceratophryidae): new state record. Check List 10: 386-387.

Santos, E. M., G. L. Silva, T. F. Campo, and M. S. Quirino. 2009. Geographic distribution: Ceratophrys joazeirensis. Herpetological Review 40: 107.

Scott Jr., N. J. and A. L. Aquino. 2005. It's a frog-eat-frog world in the Paraguayan Chaco: Food habits, anatomy, and behavior of the frog-eating anurans. Pp. 243-259 in M. A. Donnelly, B. I. Crother, C. Guyer, M. H. Wake, and M. E. White (eds.), Ecology and Evolution in the Tropics. A Herpetological Perspective. Chicago. University of Chicago Press.

Schalk, C. M., C. G. Montaña, J. L. Klemish, and E. R. Wild. 2014. On the diet of the frogs of the Ceratophryidae: synopsis and new contributions. South American Journal of Herpetology 9: 90-105.

Schalk, C. M. and C. G. Montaña. 2011. Ceratophrys cranwelli (cranwell's horned frog). Diet. Herpetological Review 42: 409-410.

Schalk, C. M. and D. Saenz. 2015. Environmental drivers of anuran calling phenology in a seasonal Neotropical ecosystem. Austral Ecology: 1-12. doi: 10.1111/ aec. 12281 .

Schalk, C. M. and L. A. Fitzgerald. 2015. Ontogenetic shifts in ambush-site selection of a sit-and-wait predator, the Chacoan Horned Frog (Ceratophrys cranwelli). Canadian Journal of Zoology 93: 461-467. 
Shine, R. 1977. Reproduction in Australian elapid snakes. II. Female reproductive cycles. Australian Journal of Zoology 25: 655-666.

Skuk, G. and F. Juncá. 2004. Ceratophrys joazeirensis. The IUCN Red List of Threatened Species. Version 2014.3. Electronic Database accessible at www.iucnredlist.org. Captured on 30 December 2014.

Toledo, L. F. and C. F. B. Haddad. 2009. Defensive vocalizations of neotropical anurans. South American Journal of Herpetology 4: 25-42.

Toledo, L. F., R. S. Ribeiro, and C. F. B. Haddad. 2007. Anurans as prey: an exploratory analysis and size relationships between predators and their prey. Journal of Zoology 271: 170-177.

Velloso, A. L., E. V. S. B. Sampaio, and F. G. C. Pareyn (eds.). 2002. Ecorregiões: Propostas para o Bioma Caatinga. Recife. Associação Plantas do Nordeste and Instituto de Conservação Ambiental The Nature Conservancy do Brasil. 76 pp.

Vieira, K. S., C. Arzabe, and W. L. S. Vieira. 2006a. Amphibia, Ceratophryidae, Ceratophrynae, Ceratophrys joazeirensis: distribution extension. Check List 2: 28-29.
Vieira, K. S., A. P. Z. Silva, and C Arzabe. 2006b. Cranial morphology and karyotypic analysis of Ceratophrys joazeirensis (Anura: Ceratophryidae, Ceratophrynae): taxonomic considerations. Zootaxa 1320: 57-68.

Wells, K. D. 2007. The Ecology and Behavior of Amphibians. Chicago. University of Chicago Press. 1400 pp.

Wilbur, H. M. 1987. Regulation of structure in complex systems: experimental temporary pond communities. Ecology 68: 1437-1452.

Wild, E. R. 1997. The ontogeny and phylogeny of Ceratophryinae frogs (Anura: Leptodactylidae). Unpublished PhD Thesis. University of Kansas, USA.

Zaidan, B. F. and F. S. F. Leite. 2012. Advertisement call of the rare, explosive breeding caatinga horned frog Ceratophrys joazeirensis Mercadal de Barrio, 1986 (Anura, Ceratophryidae). Zootaxa 3540: 65-66.

Zar, J. H. 1999. Biostatistical Analysis. Upper Saddle River. Prentice Hall, Inc. 663 pp.

Editor: Jaime Bertoluci 